\title{
Polish language as an element of identity (on the example of statements by Poles and Russians from Kaliningrad Oblast)
}

\section{KEYWORDS}

language, Polish language, language as an element of identity, Poles in Kaliningrad

\begin{abstract}
Kinga Kuszak, Katarzyna Sadowska, Polish language as an element of identity (on the example of statements by Poles and Russians from Kaliningrad Oblast). Culture Society - Education no. 2(18) 2020, Poznań 2020, pp. 129-141, Adam Mickiewicz University Press. ISSN 2300-0422. DOI 10.14746/kse.2020.18.5.2.

The article discusses the issue of Polish language as an element of identity of Poles and Russians living in Kaliningrad. The authors, during a visit to the University of Immanuel Kant, had the opportunity to do interviews with Poles and Russians living in Kaliningrad, for whom Polish is an important element of identity. The authors divided the respondents into two groups for whom Polish is an element of inherited identity and for whom Polish is an element of identity acquired in the education process. These analyzes precede reflections on the specifics and history of Kaliningrad and the kaliningrad district.
\end{abstract}

\section{Introduction}

Kaliningrad Oblast is the westernmost region of the Russian Federation. Its characteristic feature is that it is separated from the rest of the country by the

* ORCID: 0000-0002-2430-7803.

** ORCID: 0000-0002-1255-0902. 
borders of other countries and the Baltic Sea. To the east and north, the region borders on Lithuania, and to the south - on Poland. The Baltic Sea coast makes its west border. Kaliningrad Oblast is a place where the East meets the West, and where the inhabitants say 'this is no longer Russia but not quite Europe yet'. They feel distinct from the rest of the Russian Federation (Palmowski, 2019b: 356). Kaliningrad Oblast is more than $600 \mathrm{~km}$ away from the rest of the country. The region's largest city is Kaliningrad - located at the Pregol River's estuary with the Baltic Sea. It concentrates $46 \%$ of the population and $60 \%$ of the industrial potential of the Russian Federation (Palmowski, 2019a: 109). As of 2015, the city had 453500 inhabitants. Today, it is an important administrative, industrial, commercial, scientific and cultural centre of the region and the largest military centre. It is also an important scientific and academic centre. It is home to 34 scientific institutions, including six universities. The major ones are: The Immanuel Kant State University, Kaliningrad State Technical University, Baltic Fishing Fleet State Academy, Law Institute, Nakhimov Naval School, Kaliningrad Border Guard Institute (Palmowski, 2019a: 111). The nearby towns such as Svetlogorsk, Zelenogradsk, Jantar and Pionersky are Baltic Sea leisure, recreation and tourist destinations. Kaliningrad Oblast, in comparison with the rest of Russia, is characterized by a highly developed small business sector. According to Tadeusz Palmowski, there are twice as many small businesses in the region as in the whole of Russia. This is the result of privileges that the region has enjoyed since 2006, allowing goods duty-free imports into the region. This has undoubtedly contributed to the region's trade growth. On the other hand, argues T. Palmowski, the economic growth of Kaliningrad Oblast is the result of lively economic cooperation between the region's inhabitants and the neighbouring countries (Palmowski, 2019b: 356). What greatly supports the region's growth is cross-border cooperation with Poland, the distance between Kaliningrad and the Polish border being $35 \mathrm{~km}$, and the opportunities to implement joint projects co-financed from the EU funds. The projects with Polish and Kaliningrad beneficiaries have so far been related, among others, to the delivery of sewage treatment plants, road construction, and cooperation in the domains of medicine, culture and sports etc. (Palmowski, 2019b: 364). As T. Palmowski points out, "cross-border contacts have helped the communities overcome mutual barriers and prejudices and develop relatively new, formal and informal personal relationships" (Palmowski, 2019b: 364). 


\section{Kaliningrad - the city of numerous changes and cultures. An outline of the research problem}

Kaliningrad is a place with clear German, Russian and Polish influences. It is an interesting region with an extremely complicated history full of turmoil and turning points. It is a melting pot of people and cultures that have intertwined and interacted with each other for centuries. However, the city has been connected with Poland to varying degrees for centuries.

Until the Middle Ages, the area of today's Kaliningrad Oblast had been "inhabited by the Baltic Prussians, who were then conquered by the Teutonic Knights. As a result of Germanisation and German colonization, this territory came to be inhabited mainly by the German population. Nevertheless, the Polish element would play a significant role for many centuries, and the Polish language was present there (many municipal institutions employed Polish translators, the Polish language was taught at the University of Königsberg, and Polish books and magazines were published)"1. In 1253-1257, the Order of Sword Knights founded a town on the ruins of the Prussian settlement (in honour of the Czech king Ottokar II of Bohemia). Ever since, Kaliningrad was a Sambian diocese, part of the Teutonic state ${ }^{2}$. In the $15^{\text {th }}$ century, Königsberg was incorporated into Poland thanks to Casimir IV Jagiellon. The Polish region with a capital in Königsberg ceased to exist when the city was captured by the Teutonic Knights. In 1525, it became the capital of the Duchy of Prussia, dependent on the Polish king as a fief. Part of the Duchy of Prussia, Königsberg became its economic and intellectual capital. By that time, it had already become a kind of 'conglomerate of different nationalities and religions'. Prussia was open to all kinds of novelty coming from the West - Germany, Poland, the Netherlands and Italy. In 1757, the Duchy of Prussia came under the rule of the electors of Brandenburg, and the Empress Elisabeth of Russia incorporated Königsberg into the Russian Empire. It remained in the hands of the Russians until 1763. Nearly one hundred years later, in 1871, Königsberg and the whole of East Prussia were incorporated into the German Empire, the latter proclaimed in the Versailles Palace. The first ruler of the newly formed state was the Prussian king William $\mathrm{I}^{3}$. In the $20^{\text {th }}$ century, after the Second World War, pursuant to a decision made during the conference in Tehran and then confirmed in Potsdam, the great

\footnotetext{
${ }^{1}$ https://kaliningrad.msz.gov.pl/pl [access: 03.05.2019]

${ }^{2}$ https://instytutintl.pl/pl/aktualnosci/item/403-historia-kalingradu [access: 28.04.2019]

${ }^{3}$ http://encyklopedia.warmia.mazury.pl [access: 27.04.2019]
} 
powers chose to divide East Prussia into two parts: the Polish section, covering the southern section of the former East Prussia, and the northern Russian section, following the war renamed Kaliningrad Oblast. Thus, in 1945 the Red Army came to occupy East Prussia. A year later, Königsberg was renamed Kaliningrad - in honour of the Bolshevik commissioner Mikhail Kalinin (Siegień, 2016: 13). "Shortly after the borders of newly established Kaliningrad Oblast had been established, Stalin decided that it would be a closed, militarised territory with the Soviet Baltic Fleet stationed in it. As a result of the decision, for about 40 years, from the end of the war to Gorbachev's perestroika, Kaliningrad was closed to foreigners, especially from the West" (Siegień, 2016: 13). In addition, due to its heavy militarisation, the access to Kaliningrad Oblast was restricted for Soviet citizens, too. As a result of this situation, "the post-war fate of the city, an important symbol for the German culture (after all, Frederick I of Prussia crowned himself as the king of Prussia in Königsberg), remained unexplored for decades. Isolation fueled curiosity and ignited imagination" (Siegień, 2016: 13). It is then justifiable to say that until the end of the 1980s Kaliningrad Oblast had been a kind of taboo (both for the majority of Soviet citizens and for the rest of Europe), as it was "the westernmost and most heavily militarised part of the Russian Soviet Federative Socialist Republic, separated from the latter by the republics within the single federal state" (Siegień, 2016: 13). It was not until the dissolution of the USSR that the previously closed region was opened to the world. "Kaliningrad Oblast was ultimately sectioned off on 8 December 1991, when the USSR ceased to exist" (Siegień, 2016: 365). As Andrzej Sakson points out, after the collapse of the USSR, "political difficulties related to the formation of the new Russian state and the growing crisis in Russia have given rise to numerous projects aimed at further geopolitical restructuring of Kaliningrad Oblast" (Sakson, 2011: 161). The most prevalent proposals voiced in the Russian press at the time called for increasing the economic independence of Kaliningrad Oblast, granting autonomy to it; some also proposed to resettle "Russian Germans and transform the region into the German Baltic Republic as part of Russia" (Sakson, 2016: 161). We also observed realistic plans for the development of Kaliningrad Oblast from both "local scientists and Moscow and St. Petersburg experts" (Sakson, 2016: 162). These concepts aimed to develop the Oblast as a region of cooperation between the Russian Federation and the European Union and to strengthen the position of the enclave in the Russian economy. Early in the $21^{\text {st }}$ century, we saw a great deal of economic interest in Kaliningrad Oblast. The region became, among other things, the Special Economic Zone, and was also a beneficiary of the Russian Federation's programme - "Development of Kaliningrad Oblast until 2010" and the region's development strategy for 25 years, adopted 
back in 2011 (Sakson, 2016: 162). The complex history of the city, especially its most recent installment, which spans whole Europe across the 20th and $21^{\text {st }}$ centuries, is reflected in families' histories, in individual biographies. Therefore, we would like to explore some aspects of human biographies from the perspective of their cultural and linguistic identities. Further herein, we will seek to look at language as an element of human cultural identity, and then, through the prism of statements by Poles and Russians living in Kaliningrad, we will try to describe the Polish language as an element of an identity inherited from previous generations or acquired during education.

\section{Language as an aspect of individual cultural identity}

Nicolas Coupland writes that "language is probably the least understood dimension of social life" (2001). People communicate with others through language, but they often misunderstand the meanings that they convey or that are communicated to them by others. According to Edward Sapir, "real world is largely built unconsciously upon language habits of a group [...]. We can see, hear and learn in a given way because language habits of our community provide certain ways of interpretation to us" (Zarzycki, 2014: 239). When we assume that language is an element of an individual's identity, we assume that identity is constructed by that individual, is subjective, and that a person considers the language they use to be their own, even though they do not necessarily commit to investigating its nature. We can certainly argue that an individual's encounter with culture occurs through language, and that "language cannot exist in isolation from culture, i.e. from the socially inherited set of practices and beliefs that determine the substance of our lives" (Sapir, 2010: 219). As argued by Dan I. Slobin, "the content of speech conveys norms, values, and the acquired knowledge and mores of a given community" (Slobin, 2007: 358). Consequently, language becomes part of an individual's sense of identity as well as their sense of affiliation with a community. By acquiring language tools, one enters a particular community. Immersing itself in a particular language, a child learns to speak as a user of that language, be it Spanish, English, Polish or Russian, and at the same time learns how to "tell a story, make an argument, or a demand" (Slobin, 2007: 365). A child simply comes to use a particular language naturally and thinks of it as a useful tool to communicate with other people who make a particular community. Besides some overall patterns governing the acquisition of a language to the point of becoming a mature language user, we can also talk about the specific nature of one's gaining the status of a user of a particular 
language. Paul Ricoeur claims that language and the language narrative play a crucial role in shaping the sense of individual and group identities. It is no accident that linguists, psychologists, sociologists and anthropologists use the term 'speech community' - a community characterized by a common language and practices associated with it that can be observed in various everyday situations: private and professional ones (Rampton, 2000: 101). Sapir's student Benjamin Lee Whorf adds that the language that we use influences the way we think about the world. What follows from this assumption is that the 'speech community' thinks in a similar way about the world around it. This has been demonstrated with a study involving representatives of the Pyraha tribe, a small indigenous community in Brazil. The scientists found out that some categories of words in the Pyraha language were missing, especially numbers; this affects the way members of this tribe think and function as they do not use numbers, even though they can count. Three terms are used: 'one', 'two' and 'many', allowing effective functioning of the tribe members. According to Daniel L. Everett, this proves that the shortage of numbers in the Pyraha tribe is due to a cultural taboo that prohibits unnecessary generalizations beyond the 'here and now' (Everett, 2018: 345-349). The author goes on to write: "people often react with disbelief: Are you saying that a mother in the Pyraha tribe does not know how many children she has? It is so - no woman from this tribe can say whether she has one, three or six children. But she will easily name each of them and know exactly where each of them is, whether they are safe, healthy and so on" (Everett, 2018: 350). It is difficult for those of the Western culture to understand this, all the more so as they are taught from an early age that mathematics is the basic tool in the modern world. It thus would be hard not to agree with Edward Sapir's argument that "the forms of each language set a particular relation or attitude towards all content of expression possible, and via those - towards possible content of experience, obviously insofar as experience can be expressed through language" (Slobin, 2007: 361). It is therefore worth pointing out that differences between languages of the Western culture also determine individuals' experiences and thus shape their sense of identity. After all, as Dan I. Slobin points out, "every language requires the user to automatically and consistently use a set of semantic distinctions that are not directly given in everyday perception and praxis nor imposed by the requirements of practical life" (Slobin, 2007: 362). The said author goes on to say that individuals learn new things by means of language tools, which "are the only means to 'point to' relevant event categories" (Slobin, 2007: 362), and these tools are different in different languages. For culture differentiates people, even if tasks, activities and roles they pursue are, or appear to be, universal. These reflections are a starting point to address the themes related to the sense of com- 
munal identity in the inhabitants of Kaliningrad Oblast - a region where historical social, cultural, economic and other transformations have determined the fate of individuals and entire social groups originally from different language and cultural backgrounds. In this article, we are going to focus on the Polish language as an element of an inherited and chosen identity.

\section{The Polish language as an element of inherited identity on the example of Kaliningrad inhabitants}

Today, Poles living in Kaliningrad Oblast make up a group of 3900 people (Żęgota, 2002). Krzysztof Żęgota points out that the number of Poles is certainly greater than the one provided in the statistics, as some ethnic minorities in every country acknowledge the nationality represented by the majority - they do not acknowledge the nationality inherited from their ancestors. The second reason is that "during the Soviet times, national indifference was proclaimed as an official state ideology, replacing the sense of national belonging with that of the Soviet man, a kind of convenient substitute for unambiguous declarations of nationality" (Żęgota, 2002: 268). That theory, according to Swietłana Czerwonnaja, "expressed real processes of strong integration, whereby a large community was being formed, one deprived of historical memory and having no deep connections with their sources, roots, traditions of their own national cultures, or the religion of their fathers" (Czerwonnaja, 1997: 121). The affiliation with the Soviet Union was stronger than the sense of national belonging. K. Żegota points to the fact that in order to determine the number of Poles currently living in Kaliningrad Oblast, it is necessary to analyze the process of resettlement to Oblast from other areas of the Soviet Union (Żegota, 2002: 268). The largest group of Poles are the ones displaced from Kazakhstan, Siberia, Moldova, Belarus and Kyrgyzstan. These facts have also been confirmed by the results of our research. This research used the qualitative method, and the data was collected through in-depth individual interviews. The research material was gathered during a trip related to the Polish Language Days organized by the Faculty of Humanities of the Immanuel Kant Baltic Federal University on 23-30 March 2019. The personal mode of collecting research material allowed the researchers to gain insight into respondents' family and personal experiences, their subjective interpretations of these experiences and the events in which their families and themselves have participated. While telling their family stories, the participants drew attention to the difficult and complicated fate of their parents and grandparents as follows: "my grandmother came to Kaliningrad from Lithuania in 1957. 
She came from Vilnius in search of work and better living conditions after the war", "my father had a military job, my family came from Belarus during Soviet times", "my family came from the village of Vileyka - the region of Minsk, Belarus", "we came from the former territory of the Republic of Poland - it is now Belarus", "we came from Kazakhstan, we wanted to be as close to Poland as possible", "in 1962, my family came from Vilnius". The statements we have gathered reflect the migration of the people of Polish origin from the more distant parts of the Soviet Union towards the border with Poland. Those Poles are also, according to the statistics, the most numerous group of Karta Polaka holders (Górny, Kindler, 2008: 226). Many of today's Poles living in Kaliningrad Oblast are descendants of the inhabitants of Poland who had suffered repressions many years ago - they were deprived of their roots, identity and language. Therefore, the difficult generational experience determines the way today's Poles living in Kaliningrad articulate their identity. Some of them define themselves as Polish men and women, for example, e.g.: "I am Polish, I cultivate Polish traditions in my family". Others speak the way two of our respondents did: "I am Russian and Polish", "I represent a mix of Polish and Russian cultures. Others define their identity as follows: I am a man of the world", one of our respondents said. While analysing the linguistic situation of Poles in the USSR, Józef Byczkowski noticed that in 1959 the Polish language was spoken by $45,2 \%$ of all Poles, in 1970 the Polish as a mother tongue was indicated by $32,5 \%$ of Poles, and in 1979 - only by 29,1\% (Byczkowski, 1990: 137-138). This historical situation may inform the answers we have received about the national identity of some of the respondents. The inhabitants of Kaliningrad Oblast, asked about the language they use to communicate with their close relatives and friends, provided the following responses: 'Russian,' 'Russian, rarely Polish', 'unfortunately in Russian but we want to learn Polish', 'in Polish and in Russian. The following situation has been described by one of our respondents: "The Polish community in Kaliningrad are mainly people who have learned Polish as adults. Despite their sense of affiliation with Poland, Polish traditions, etc., the Polish language is a foreign language to them. However, they want their children to learn Polish, too". The educational policy of the Russian Federation has been informed by previous assimilation experiences with respect to the displaced population. Hence, as our respondents stress: "there are no Polish schools in Kaliningrad. There are (few) schools where students can choose Polish as their second or even third foreign language after English and/ or German. These are mostly children who do not have Polish origin. It's just that their parents think it's worth learning their neighbours' language". As a result, the youngest generation does not speak Polish or speaks the language poorly, almost solely with their closest relatives and friends. 
However, Poles living in the territory of Kaliningrad Oblast exercise their right to maintain their national and cultural identity and belong to independent Polish organizations. Presently, there are ten of them, the three largest being:

- Autonomia Polaków w Kaliningradzie „Polonia”;

- Stowarzyszenie „Dom Polski” im. Fryderyka Chopina in Chernyakhovsk;

- Wspólnota Kultury Polskiej im. Jana Kochanowskiego in Ozyorsk;

In addition, the region is home to the following communities and associations:

- Wspólnota Kultury Polskiej in Baltiysk;

- Stowarzyszenie Inicjatyw Polonijnych in Kaliningrad;

- Wspólnota Kultury Polskiej in Gusev;

- Polesska Rejonowa Organizacja Społeczna „Stowarzyszenie Kultury Polskiej Królowa Jadwiga";

- Wspólnota Kultury Polskiej in Znamensk;

- stowarzyszenie polonijne Związek Młodzieży „Polonez”;

- stowarzyszenie polonijne Królewiczanie.

Two of them (Autonomia Polaków w Kaliningradzie „Polonia”, „Dom Polski” in Chernyakhovsk) are licensed to issue the certificates attesting one's active contribution to fostering Polish language and culture. They are also entitled to issue the so-called Karta Polaka cards.

In addition, important institutions maintaining the Polish culture and language in Kaliningrad Oblast are Catholic parishes, of which there are about 20 in the region, two of which in Kaliningrad itself. Through typical Polish rituals, they help maintain their sense of national identity and affiliation with the country, as demonstrated by their statements: "just like in Poland, we eat eggs, we consecrate baskets", "for Christmas, we sing Christmas carols, we share wafers; and for Easter, we make palms and Easter eggs", "painting eggs, the Easter cake", "wafer, Christmas Eve meetings, singing Polish carols", "for Christmas Eve, we have twelve dishes, just like in Poland". "We try to go to church every week and attend pilgrimages".

An interesting initiative aiming to keep up the Polish language and culture was described by one of our respondents: "Recently, an idea has emerged to set up a club where mothers with children could come and play together and speak Polish, although it is yet to be developed. These mothers are graduates of our Polish studies and would like someone to teach Polish to their kids. As there are no such activities in our city, they consider organizing such meetings on their own". It is an example of the commitment to passing the language, tradition, culture and the sense of national identity on to the youngest generation of Poles. 


\section{The Polish language as an element of chosen identity on the example of Kaliningrad inhabitants}

Kaliningrad Oblast is a region where great interest in our country, language and culture can be seen due to the proximity to Poland. At the Faculty of Humanities of the Immanuel Kant Baltic Federal University, students have the opportunity to study Polish. They do use this opportunity. They do that for various reasons. "When I was studying at school, I was fascinated by the English language. I wanted to become an English teacher. But unfortunately I could not enroll in the English programme for various reasons, and then I was advised to consider a new faculty - the Polish studies. I did not know that it existed in the first place. I agreed and did not regret it even for a second" (W 1), said one of the graduates of the Faculty. Another one adds: "My adventure with Polish started a very long time ago, when I was 10 years old. My mother and I went on a trip to Poland for the first time ever, then we bought a Polish language textbook and it stayed put on the shelf until additional Polish classes were introduced at my school. In the ninth grade, 25 people started going there, and then in the eleventh grade there were four of us. I found out that we had a Polish language department at the university and I said why not? I had neither Polish roots nor friends in Poland, and yet I had a passion for that culture, it was easy for me to learn Polish words by heart" (W 2).

The Polish studies were an opportunity to learn not only the language but also Polish culture: "From 2004 to 2009, I was a diligent student of Polish philology. Those were probably the best years of my life. We kept travelling around Poland, summer schools, internships, recitation competitions at the consulate, articles for the Polish newspaper... This is what my anthem is about. I can talk about it for hours on end..." (W 2). Another of our respondents describes her decision to choose Polish philology as follows: "At the end of high school, I decided that I would like to study philology, but at first I was thinking about Russian philology. I decided to talk about it with an older friend, who was about to graduate in Russian studies at the local Kant University (which was not yet named so at the time). She told me that the Polish studies programme was established as part of the Faculty of Slavic Philology and she advised me to try my hand at that. This is how I have chosen my path in life" (W 8). The graduates of Polish studies have shared their findings related to the Polish language with us. One of the respondents talked about how she learned about the Poznań writer Małgorzata Musierowicz: "During my first year at the university, I went with my parents to Gdańsk to visit their Polish friends, who they had not seen for over 15 years. At that time, I could already speak Polish (quite fluently, although with mistakes). Mrs. Renata, a friend of my 
parents, offered me to take home three books by Małgorzata Musierowicz, whom I did not know at the time, and return them at the next meeting. I did not find their covers interesting (probably because of the slightly childish cover images), but I thanked her and took the books home. I later used one of them, it was Noelka, and I started reading it. Noelka była mocna i zdrowa jak orzech (Noelka was as strong and healthy as a nut). I am writing this first sentence from memory. I could not stop reading that book. I read these three books in no time, and then I started collecting the Jeżycjada series. Now I have all of the books by Mrs Musierowicz. I know some of them almost by heart. They have always accompanied me in the difficult moments of my life. And I am sure that this passion helped me learn Polish, and the richness of the language spoken by the author helped me win Polish writing competitions several times" (W 8). This demonstrates how social circles determine one's interests - including language interests - and contribute to their affiliation with a particular culture.

The respondents' statements show that learning and exploring the Polish language is associated with personal satisfaction and brings measurable opportunities for professional development: "Many people want to learn Polish because they often go shopping in Poland and can develop business contacts with Poland" (W 3). These statements help us understand why Polish language studies are a popular field of study. The advantages associated with the use of the Polish language are also mentioned by another respondent, who said that: "In Kaliningrad, the interest in the Polish language is on the rise as we are neighbours" (W 4). During the interviews, the respondents pointed to the fact that great interest in Polish culture is observed especially in schools (W 5) and the cultivation of Polish customs, e.g. the Christmas ones: "We sing carols in Polish" (W 6), "We set up a crib, listen to Christmas carols and contemporary songs in Polish, read passages of the Bible in Polish" (W 7).

Our respondents revealed their authentic passion for the Polish language and the work associated with it: "After graduation, I took up teaching Polish and have since done it daily. My work is also my passion" (W 8). Do the Polish philology graduates feel happy with their prospects for professional development? "I have never ever regretted that I tied my life with the Polish language. It is the job that keeps looking for me, not the other way around. I have taught Polish for 10 years. I work at the Expert language school in Kaliningrad. Now I am on maternity leave, my son is 14 months old, but I have been working a little bit lately" (W 1). For many of them, career is an important part of their lifestyles. They have pointed out that they wanted to promote the Polish language both at work and in their private lives. Interestingly, one of our respondents is talking to her child only in Polish: 
"I started teaching Polish to my child because I wanted to pass on my knowledge of and love for the language and country. Thanks to the location of Kaliningrad, we leave for Poland quite often (anyway, much more often than elsewhere), so it might be useful to speak Polish. In addition, when I was studying Teaching Polish as a Foreign Language at the Jagiellonian University, I heard and read a lot about bilingual children and I was very interested in that. It was a kind of experiment to see if it works the way it is presented in books. In Russia, mothers can spend three years on maternity leave. It is quite a long time, and the language can get a bit rusty if you do not use it. That is why I started talking to my daughter, so as not to forget the language and keep it at a decent level. We read books I buy in Poland, we watch cartoons in Polish and listen to songs and audiobooks" (W 2). This is an example of how the people of Kaliningrad choose for themselves and their children a language that becomes part of their identity and their culture.

\section{Conclusion}

The difficult and complicated biographies of contemporary Poles and Russians living in Kaliningrad Oblast (and their ancestors) certainly require further indepth research and analysis. This study is only a sketch for further research work. Our goal was to highlight the fact that individuals define their sense of belonging to a language group through the experiences of previous generations (covered in oral stories and written documents), but also their own experiences - the most recent ones. They define the Polish language as the one that determines their individual identity. Given the historical specificity of Kaliningrad Oblast, a kind of melting pot of cultures, languages, shifting borders and displaced national groups and the current proximity to the border, Ludwig Wittgenstein's conceptualization - "the borders of my language are the borders of my world" - takes on a different meaning.

\section{Bibliography}

Achremczyk S. (2005), Olsztyńskie badania dziejów Królewca i Kaliningradu po 1945 roku, „Komunikaty Mazursko-Warmińskie", no. 3.

Byczkowski J. (1990), Polonia w Europie, Opole.

Coupland N. (2001), Introduction: Sociolinguistic Theory and Social Theory, in: Sociolinguistics and Social Theory, eds. N. Coupland. S. Srangi, Ch.N. Candlin, London. 
Czerwonnaja S. (1997), Wieloetniczny kompleks współczesnej kultury rosyjskiej: dialog czy konfrontacja religii, narodów, państw, in: Dylematy tożsamości europejskich pod koniec drugiego tysiąclecia, eds. J. Mucha, W. Olszewski, Toruń.

Everett D.L. (2018), Język. Narzędzie kultury, Kraków.

Górny A., Kindler M. (2008), Cudzoziemcy w Polsce na przełomie XX i XXI wieku, in: 25 wykładów o migracjach, eds. M. Lesińska, M. Okólski, Warszawa.

Palmowski T. (2019a), Nowe modele współpracy Gdańska i Kaliningradu, https://depot.ceon.pl [access: 11.04 .2019$]$.

Palmowski T. (2019b), Obwód kaliningradzki i jego wspótczesne dylematy, www.journals.pan.pl [access: 11.04.2019].

Rampton B. (2000), Continuity and Change in Views of Society in Applied Linguistics, „Urban Language \& Literacies".

Sakson A. (2011), Geostrategiczne aspekty „problemu kaliningradzkiego”, „Przegląd Strategiczny”, no. 2.

Sapir E. (2010), Język. Wprowadzenie do badań nad mową, Kraków.

Sidorkiewicz R. (2019), Dziedzictwo historyczne współczesnego Kaliningradu, http://akant.org/ archiwum/219-swiat-inflant/swiat-inflant-2018/swiat-inflant-2018-nr-1/6558-roman-sidorkiewicz-dziedzictwo-historyczne-wspolczesnego-kaliningradu-1 [access: 22.04.2019].

Siegień P. (2016), Königsberg i Kaliningrad - między pamięcia, utratą i zapomnieniem, „Problemy Rozwoju Miast", r. XIII, z. II.

Sikorski J., Jasiński J. (2014), Mikołaj Kopernik, Immanuel Kant. Dwie najwybitniejsze postacie nauki na ziemiach niegdyś pruskich, Olsztyn.

Slobin D.I. (2007), Od użytkownika języka dziecięcego do użytkownika języka ojczystego, in: Psychologia języka dziecka. Osiagnięcia, nowe perspektywy, eds. B. Bokus, G.W. Shugar, Gdańsk.

Zarzycki Ł. (2014), O językowej tożsamości człowieka w kontekście dyskursu religijnego, „Studia Językoznawcze", no. 5.

Żęgota K. (2002), Liczebność diaspory polskiej w obwodzie kaliningradzkim Federacji Rosyjskiej. Zarys problematyki, „Środkowoeuropejskie Studia Polityczne”, no. 1 (12).

\section{Netography}

http://encyklopedia.warmia.mazury.pl/index.php/Kr\%C3\%B3lewiec [access: 27.04.2019]

https://instytutintl.pl/pl/aktualnosci/item/403-historia-kalingradu [access: 28.04.2019]

https://kaliningrad.msz.gov.pl/pl/informacje_konsularne/opieka_konsularna/polak_w_ok/

polak_w_ok [access: 03.05.2019] 
